\title{
Effectiveness of Adapted Science Instruction for Teaching Learning of Science Temperature Concept among Students with Visual Impairment \\ M.Revathi1 and G. Victoria Naomi2
}

1Ph.D. Scholar, Department of Special Education, Avinashilingam Institute for Home Science and Higher Education for Women, Coimbatore, India 2Professor and Head, Department of Special Education, Avinashilingam Institute for Home Science and Higher Education for Women, Coimbatore, India

\begin{abstract}
The areas of science and mathematics have traditionally been inaccessible to students with Visual Impairment. Hence it needs adapted materials and instructional methods to understand and perform science experiments by visually impaired. This study aims to study the Effectiveness of Adapted Science Instruction on Leaning of Science Temperature Concept among students with Visual Impairment. The Investigator adapted the Science Temperature concept Activities as per the needs of Students with Visual Impairment. Visually Impaired sample from Grade VI to VIII were trained and effectivess of the Adapted Instruction was found.
\end{abstract}

Keywords: Visually Impaired, Science, Temperature Concept, Adapted Instruction

\section{Introduction}

Science learning should be accessible by all learners including the student with special educational needs. Science Education for All is one of the manifestations of Education for All. Visually Impaired have the limitation to obtain information through their eyesight sense. The areas of science and mathematics have traditionally been inaccessible to students with Visual Impairment. Fields such as chemistry, physics, engineering, biology, and mathematics are common with visually-presented concepts and information. This visual information has not been made available for widespread use in a format easily accessible to Visually Impaired students. This study aims to study the Effectiveness of Adapted Science Instruction on Leaning of Science Temperature Concept among students with Visual Impairment.

\section{Objectives}

To find out the Effectiveness of Adapted Science Instruction on Teaching Learning of Science Temperature Concept among Visually Impaired students

\section{Methodology}

The study consisted of two basic step.

At the first step of the study, teaching materials and Activities were adapted in terms of Visually Impaired students' learning needs.

At the second step the implementation of the Adapted Temperature Activities to Students with Visual
Impairment was done and the effectiveness of adaptation was presented.

The study was conducted in High Schools from Coimbatore and Madurai Districts of Tamilnadu, India. The sample from Grade VI to VIII was selected Training.

Adaptation of Temperature Experiments

Science Temperature Activities from Grade VI to VIII were adapted in terms of Materials and Procedure. The Adaptation of material includes Braille note, Large print, Tactual markers, Talking Aids were used.

The Adaptation of procedure includes the activities were involved effective use of other senses such as touch and hearing.

\section{Implementation}

The following standards were set while the activities were implemented:

1. The existing knowledge of the students was tried to be elaborated before each activity.

2. Enough time was given to each student to investigate the activity materials by touching.

3. Student activity guide were distributed for each student before the activity.

4. The teacher allowed students to do each activity on his own. 
5. Student safety is emphasized at every stage and precautions were told initially.

6. Students' active involvement was reinforced to learn concepts better.

\section{Results}

7. Students were taken note about each concept at the end of the activity.

\begin{tabular}{|l|l|l|r|r|l|}
\hline Variable & Testing & N & \multicolumn{1}{|l|}{ Mean } & Std. Deviation & t-test \\
\hline \multirow{2}{*}{ Temperature Science Concept } & Pretest & 30 & 9.08 & 2.84 & $3.5^{*}$ \\
\cline { 2 - 5 } & Posttest & 30 & 10.33 & 2.47 & \\
\hline
\end{tabular}

From table 1 it is evident that the t-value for Temperature Science Concept is significant at 0.01 level. It indicate that Visually Impaired Students have secured higher score than students in Post test than pre test,
Hence it is concluded that the intervention was found to be effective in enhancing in acquiring science temperature concepts.

\begin{tabular}{|l|l|l|r|l|l|}
\hline Variable & Testing & N & Mean & Std. Deviation & t-test \\
\hline Performance in Science & Pretest & 30 & 4.95 & 2.04 & $3.4 * *$ \\
\cline { 2 - 6 } Temperature Concept Activities & Posttest & 30 & 5.99 & 2.27 & \\
\end{tabular}

From table 2 it is clear that the t-value for Performance Science Temperature Concept Activities is significant at 0.01 level. It indicate that Visually Impaired Students have secured higher score than students in Post test after intervention than pre test. Hence it is concluded that the

\section{Conclusion}

Students with Visual Impairment can participate in experiments and gain experience with Temperature Activities when provided with simple material adaptations or modifications. Taking into consideration

\section{References}

1. Annable, G., Goggin, G., \& Stienstra, D. (2007). Accessibility, disability, and inclusion in information technologies: Introduction. Information Society, 23(3), 145-147

2. Arter, C., Mason, H. L., McCall, S., McLinden, M., \& Stone, J. (1999). Children with visual impairment in mainstream settings. London: David Fulton Publishers.

3. Hadary, D. \& Cohen, S. (1978). Science activities for blind, deaf, and emotionally disturbed students. College Park, MD: University Park Press.

4. Holahan, G. G., McFarland, J., \& Piccillo, B. A. (1994). Elementary school science for students with disabilities. Remedial and Special Education, 15(2), 86-93.

5. Kızılaslan, A. \& Sözbilir, M. (2017). Analysis of an activity designed for students with visual impairment according to science process skills. 10. . null hypothesis stated that there is no significant difference between the performance of visually impaired students in Science Temperature Concept Activities is rejected.

the individual needs of the students, it is possible to facilitate the scientific knowledge achievement of the individuals by simple and effective activities and materials prepared for students with visual impairment by putting different senses into the foreground during the education process. Students should be able to learn the basic concepts through Adapted Instruction.

SDU International Journal of Educational Studies, 4(2), 86-95.

6. Kumar, D., Ramasamy, R., \& Stefanich, G. (2001). Science for students with visual impairments: Teaching suggestions and policy implications for secondary educators. Electronic Journal of Science Education, 5(3). Article 4. Retrieved from

7. Mastropieri, M. A. \& Scruggs, T. E. (1995). Teaching science to students with disabilities in general education settings. Teaching Exceptional Children, 27(4), 10-13.

8. Ricker, K. S. \& Rodgers, N. C. (1981). Modifying instructional materials for use with visually impaired students. The American Biology Teacher, 43(9), 490-501.

9. Sözbilir, M. (2016). Practical work in science with visually impaired students. In I. Eilks, S. Markic, \& B. Ralle (Eds.), Science education research and practical work (pp. 169-179). Aachen: Shaker Verlag 